Original Paper

doi $\underline{10.15826 / \text { recon.2019.5.2.006 }}$

\title{
The role of e-government systems in ensuring government effectiveness and control of corruption
}

\section{E. Agbozo $\bowtie$, B. K. Asamoah \\ Ural Federal University, Ekaterinburg, Russia; e-mail: eagbozo@urfu.ru}

\author{
KEYWORDS \\ government effectiveness, \\ e-government, rule of law, control \\ of corruption, citizen-centric \\ governance, government policy
}

\section{FOR CITATION}

Agbozo, E., \& Asamoah, B. K. (2019) The role of e-government systems in ensuring government effectiveness and control of corruption. R-economy, 5(2), 53-60. doi: 10.15826/recon.2019.5.2.006

\section{Роль систем электронного правительства в обеспечении эффективности государственного управления и контроля коррупции}

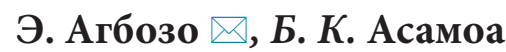 \\ Уральский федеральный университет, Екатеринбург, Россия; е-таil: eagbozo@urfu.ru
}

\begin{abstract}
АННОТАЦИЯ
Системы электронного правительства являются частью общего процесса цифровой трансформации в государственном секторе: странам с эффективным электронным правительством удается снизить административную нагрузку на частные лица и предприятия, а также повысить эффективность, прозрачность и подотчетность правительства. Эта статья раскрывает связь между развитием систем электронного правительства и такими факторами, как верховенство закона и борьба с коррупцией. Исследование опирается на модель роста, которая была построена и статистически протестирована с использованием линейного регрессионного анализа для проверки достоверности элементов модели. В модели используются три показателя, рассчитываемые Всемирным банком: верховенство закона, борьба с коррупцией и эффективность правительства. Данные для измерения индекса развития электронного правительства (EGDI) в пятнадцати странах были предоставлены в рамках Обзора электронного правительства 2016 года, проведенного ООН. Полученные данные свидетельствуют о позитивной взаимодополняющей взаимосвязи между верховенством закона в стране и развитием системы электронного правительства, которая повышает эффективность правительства. В статье описывается сдвиг в сторону более ориентированной на граждан стратегии внедрения электронного правительства, которая может быть рекомендована, в частности, лицам, определяющим политику в развивающихся странах. Предложенная модель может быть рекомендована в качестве инструмента оценки эффективности государственного управления в любой стране.
\end{abstract}

(c) E. Agbozo, B. K. Asamoah, 2019

\section{КЛЮЧЕВЫЕ СЛОВА}

эффективность правительства, электронное правительство, верховенство закона, борьба с коррупцией, гражданское управление, государственная политика

\section{ДЛЯ ЦИТИРОВАНИЯ}

Agbozo, E., \& Asamoah, B. K. (2019) The role of e-government systems in ensuring government effectiveness and control of corruption. R-economy, 5(2), 53-60. doi: 10.15826/recon.2019.5.2.006 


\section{Introduction}

Just as technological innovation is aimed at optimizing the business process or the work of enterprises and at giving them a competitive advantage, e-government is aimed at improving the efficiency, effectiveness and transparency of governance and public service delivery [1]. The aim of innovation in the public sector, that is, electronic government (or e-government), is to provide quality public service delivery, reduce stress and bureaucracy in accessing public services, build trust in government and government accountability to its citizens and users [2]. Apart from improving citizens' access to public services and being a transformative tool [3], e-government also makes it possible to promote business to business (B2B) networking, acting as a link between businesses and enabling resource flow and efficient communication [4].

In recent years, e-government research and implementation has transitioned into the phase of citizen-centric or citizen-centered e-government, which seeks to put citizens at the core of these public service innovations $[5 ; 6]$. For a long period, most governments have focused on infrastructure provision rather than on satisfying the citizens/users (the main reason why these implementations exist) [7;8]. That being said, if citizen-centric e-government is fully embraced and implemented effectively, it will enhance user satisfaction and increase government effectiveness.

For e-government to successfully fulfil its purpose in any given environment, the following factors are necessary: citizen satisfaction, security, privacy and trust, support from the government, ICT skills, facilities offered, efficiency, innovative thinking, strategic ICT thinking within government, rule of law, availability of ICT infrastructure and ICT amenities $[9 ; 10]$.

This study investigates e-government and its influence on government effectiveness by building a model which takes into account certain factors and tests them.

This paper is organized as follows. The next section provides a review of the research literature on this problem. After that, in the methodology section, we are going to describe our research model and postulate the hypotheses we are going to test. Then, we are going to discuss the findings, and the final section concludes and discusses the policy implications of the results.

\section{Literature Review}

This study is centered on effective governance, which is achievable when e-government is citizen-centric. A citizen-centric e-government system encourages users to interact more freely and effectively with their governments and thus leads to enhancement of the quality of public services [5]. A citizen-centric e-government involves participation of users/citizens [6] before, during and after the delivery of e-government services. Governments must fully transform from agency-centric to citizen-centric in order for e-government capabilities to be fully realized [11].

Eger \& Maggipinto pointed out that e-government does not encompass technology alone but also includes rules and procedures. Thus, their study concludes that "e-government operates under the Rule of Law, protecting general principles such as equality, administrative transparency, rights protection for all citizens" [12, p. 23]. This assertion indicates the significant role played by the rule of law in any successful e-government endeavor. The rule of law is a powerful anti-corruption predictor and e-government has the potential of curbing corruption [13].

When the rule of law is upheld and followed, it leads to development and prosperity. The rule of law contributes to the protection of such core values as human freedom, which, in its turn, fosters an environment for economic development [14]. Socio-economic development policies are at the heart of e-government initiatives [15]. Thus, e-government development and economic development are interdependent. This means that in an environment where the rule of law is supported by institutions, e-government systems can flourish. E-government cannot be successful in chaotic systems (primarily where the rule of law is violated), which can be illustrated by an example of corruption in developing economies, which leads to the failure of e-government projects [16].

Previous studies failed to examine the effect of e-government on government effectiveness. For example, Ifinedo [17] theorized models yet did not provide sufficient evidence to demonstrate the positive influence of the rule of law on e-government growth in transition economies of Central and Eastern Europe. Krishnan \& Teo [18] focused on e-government maturity, using the growth model to determine the value of good governance on e-government maturity. Another study [19] focuses on government efficiency and e-government growth. 
Our study focuses on another aspect - on the impact of e-government development on effective governance. We are going to address the following research questions:

1. Does the rule of law influence the development of e-government and corruption control?

2. Does e-government development influence corruption control?

3. Does e-government development enhance government effectiveness?

The next section outlines the research model and posits the hypotheses.

\section{Research Model and Hypotheses}

To answer the research questions and test the hypotheses, we need to develop a viable methodological framework [20]. Model validation and model development are necessary for research because they enhance our knowledge base and also provide the empirical basis for the construction of a comprehensive theory for further studies [21].

The research model for this study consists of the following components: the rule of law, corruption control, e-government development, and government effectiveness.

\section{Rule of law}

According to the World Justice Project, the rule of law is defined by these four universal principles: accountability, just laws, open government, and accessible and impartial distribution of justice $^{1}$. In other words, the strong adherence to formal procedures and requirements is crucial [22]. The factors considered in the Rule of Law Index include: (1) constraints on government powers, (2) absence of corruption, (3) open government, (4) fundamental rights, (5) order and security, (6) regulatory enforcement, (7) civil justice, (8) criminal justice and (9) informal justice. Thus, the rule of law index is considered in this study as a representation of the rule of law in any given country.

\section{Corruption control}

Mungiu-Pippidi and Dadašov [23] describe corrupt activities as a result of individual behavior by self-seeking agents (bureaucrats), who abuse their position for personal gains and thereby betray top-level policy-makers' interests. Furthermore, the researchers highlighted the fact that corruption is a function of monopoly power over

${ }^{1}$ What is the Rule of Law? Retrieved from: https://worldjusticeproject.org/about-us/overview/what-rule-law (Accessed 10 August 2018) a good or service, the discretion to decide who receives it, and the degree of accountability of public authorities [23]. Our study uses the World Bank Group's World Governance Indicator - control of corruption, which captures perceptions of the extent to which public power is exercised for private gain, including both petty and grand forms of corruption, as well as exploitation of the state by elites and private interests ${ }^{2}$.

As such, anti-corruption policies are used by policy-makers to ensure effective governance. Corruption control is an important component to be included into our model.

\section{E-government development}

Research on e-government has investigated monitoring and evaluation of public sector e-services and infrastructure maturity over different periods. Benchmarking of e-government maturity performed by the United Nations ${ }^{3}$ is a comprehensive assessment of the distribution of e-government in various governments across all nations. The $2016 \mathrm{UN}$ report highlighted the following key points as factors which determine the development of e-government: the existence of Whole-of-Government Approaches (WGAs), e-participation, open government data or electronic and mobile services. Hence, e-government development requires strong political commitment, government-wide vision, collaborative leadership, as well as appropriate legislation and holistic institutional frameworks ${ }^{4}$. E-government development influences national progress [24].

This study associates e-government development with the UNDESA's e-Government Development Index (EGDI).

\section{Government effectiveness}

Government effectiveness encompasses the ability of the government to provide quality public services and its ability to formulate credible and quality policies [25]. Government effectiveness has a positive impact on innovation and so-

\footnotetext{
2 World Bank (2016). The Worldwide Governance Indicators (WGI) project. Retrieved from: http://info.worldbank.org/ governance/WGI/ (Accessed 10 August 2018)

${ }^{3}$ United Nations (2016). United Nations e-government survey 2016: e-government in support of sustainable development. New York. Retrieved from: http://workspace.unpan. org/sites/Internet/Documents/UNPAN97453.pdf (Accessed 10 August 2018)

${ }^{4}$ United Nations (2016). United Nations e-government survey 2016: e-government in support of sustainable development. New York. Retrieved from: http://workspace.unpan. org/sites/Internet/Documents/UNPAN97453.pdf (Accessed 10 August 2018)
} 
cio-economic activities of companies and enterprises, creating perfect conditions for economic prosperity [26].

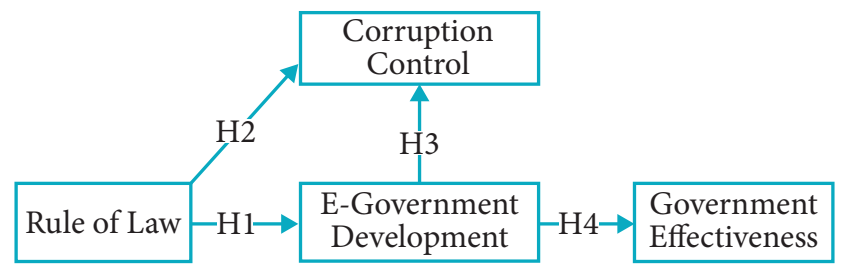

Figure 1. Proposed research model

Figure 1 illustrates the proposed research model. The rule of law influences e-government development and the control of corruption. E-government development has a significant impact on the control of corruption and, most importantly, on government effectiveness.

The next section expounds on the methodology of the study.

\section{Methodology}

For the purpose of this study, we used three (3) governance indicators for 2016 from the World Bank's Governance Indicator project - the rule of law, control of corruption, and government effectiveness ${ }^{5}$. The e-Government Development Index (EGDI), the indicator which measures e-government performance country-wise, was derived

${ }^{5}$ World Bank (2016). The Worldwide Governance Indicators (WGI) project. Retrieved from: http://info.worldbank.org/ governance/WGI/ (Accessed 10 August 2018) from the UN's e-Government 2016 Survey [25]. The reason for selecting 2016 was due to the fact that these are the most recent data available for the EGDI indicator on the current state of e-government in all countries.

In selecting the countries for our comparative analysis, we chose three countries from each continent. One country was selected for each of the EGDI ranges: 0-0.39 (low), 0.4-0.59 (medium), and $0.60-1$ (high). The countries and their respective indicators are shown in Table 1.

For the purpose of this study and due to the numerical nature of variables, a linear regression analysis was performed on the presented data set in the $\mathrm{R}$ programming language. The study explored the relationship between the dependent and independent variables for each scenario (hypothesis) of the model (see Figure 1).

The regression analysis was chosen for this study because it allows us to identify mathematical relationships between dependent and independent variables as well as describe the impact that an independent variable has on a dependent variable [28]. Thus, a simple linear regression analysis was used to verify the association between each interconnected component of the proposed model.

The results were expressed as the quality of the adjusted model called R-squared $\left(R^{2}\right) . R^{2}$ ranges from 0 to 1 and describes the amount of variation in the response that is explained by the least squares line [29].

Table 1

Countries and selected indicators for 2016

\begin{tabular}{|c|c|c|c|c|c|}
\hline Region & Country & $\begin{array}{c}\text { E-government } \\
\text { development index }\end{array}$ & $\begin{array}{l}\text { Government } \\
\text { effectiveness }\end{array}$ & Rule of law & $\begin{array}{c}\text { Control } \\
\text { of corruption }\end{array}$ \\
\hline \multirow{3}{*}{ Africa } & Mauritius & 0.6231 & 1.0 & 0.8 & 0.3 \\
\hline & Ghana & 0.4182 & -0.2 & 0 & -0.2 \\
\hline & Guinea & 0.1226 & -1.0 & -1.3 & -0.9 \\
\hline \multirow{3}{*}{ Americas } & USA & 0.8420 & 1.5 & 1.7 & 1.3 \\
\hline & Cuba & 0.3522 & -0.1 & -0.4 & 0.1 \\
\hline & Bolivia & 0.4821 & -0.6 & -1.2 & -0.7 \\
\hline \multirow{3}{*}{ Asia } & Republic of Korea & 0.8915 & 1.1 & 1.1 & 0.4 \\
\hline & Jordan & 0.5123 & 0.1 & 0.3 & 0.3 \\
\hline & Pakistan & 0.2583 & -0.6 & -0.8 & -0.9 \\
\hline \multirow{3}{*}{ Europe } & Finland & 0.8817 & 1.8 & 2.0 & 2.3 \\
\hline & Belarus & 0.6625 & -0.5 & -0.8 & -0.3 \\
\hline & Albania & 0.5331 & 0 & -0.3 & -0.4 \\
\hline \multirow{3}{*}{ Oceania } & Australia & 0.9143 & 1.6 & 1.8 & 1.8 \\
\hline & Papua New Guinea & 0.1882 & -0.7 & -0.8 & -0.9 \\
\hline & Samoa & 0.4019 & 0.5 & 0.8 & 0.3 \\
\hline
\end{tabular}

Source: World Bank (2016). The Worldwide Governance Indicators (WGI) project. Retrieved from: http://info.worldbank.org/ governance/WGI/ (Accessed 10 August 2018); United Nations (2016). United Nations e-government survey 2016: e-government in support of sustainable development. New York. Retrieved from: http://workspace.unpan.org/sites/Internet/Documents/UNPAN97453.pdf (Accessed 10 August 2018). 


\section{Research Findings}

This section presents the results of the analysis performed on the given data (see Table 2) by using the selected linear regression test. In the sub-sections below we describe the results of the relationship test.

\section{Rule of Law and E-Government Development $($ RoL $\rightarrow$ EGDI)}

First, we tested the following hypothesis:

H1: The presence and effectiveness of the rule of law has a positive and significant effect on e-government development in any country.

Regression coefficients on e-government development (EGDI)

\begin{tabular}{|l|c|c|c|c|}
\hline $\begin{array}{c}\text { Independent } \\
\text { Variable }\end{array}$ & $\boldsymbol{\beta}$ & $\boldsymbol{t}$ & $\boldsymbol{P r}(>|\boldsymbol{t}|)$ & Result \\
\hline RL.EST & 0.05306 & 3.607 & $0.00319 * *$ & Supported (H1) \\
\hline & $\begin{array}{l}\text { Significance codes: } \\
* p<0.05, * * \\
p<0.01 ; * * * \\
\text { Adjusted } R \text {-squared: } 0.4618\end{array}$ \\
\hline
\end{tabular}

\section{Rule of Law and Corruption Control} $(\mathrm{RoL} \rightarrow \mathrm{CoC})$ lows:

The second hypothesis to be tested was as fol-

$\mathrm{H} 2$ : The presence and effectiveness of the rule of law has a positive and significant effect on control of corruption in any country.

Table 3

\section{Regression coefficients on corruption control} (CC.EST)

\begin{tabular}{|c|c|c|c|c|}
\hline $\begin{array}{c}\text { Independent } \\
\text { Variable }\end{array}$ & $\beta$ & $t$ & $\operatorname{Pr}(>|t|)$ & Result \\
\hline RL.EST & 0.1546 & 3.188 & $0.00781 * *$ & Supported (H2) \\
\hline & \multicolumn{4}{|c|}{$\begin{array}{l}\text { Significance codes: } \\
* p<0.05, * * p<0.01 ; * * * p<0.001 \\
\text { Adjusted } R \text {-squared: } 0.7948\end{array}$} \\
\hline
\end{tabular}

\section{E-Government Development} and Corruption Control (EGDI $\rightarrow \mathrm{CoC}$ )

The third hypothesis looked the following way:
H3: E-Government development (effectiveness and quality of service delivery) has a positive and significant effect on the level of corruption control in any country.

Table 4

Regression coefficients on corruption control (CC.EST)

\begin{tabular}{|l|c|c|c|c|}
\hline $\begin{array}{c}\text { Independent } \\
\text { Variable }\end{array}$ & $\boldsymbol{\beta}$ & $\boldsymbol{t}$ & $\boldsymbol{P r}(>|\boldsymbol{t}|)$ & Result \\
\hline EGDI & 1.6445 & 2.544 & $0.02575^{*}$ & Supported (H3) \\
\hline & $\begin{array}{l}\text { Significance codes: } \\
* p<0.05, * * p<0.01 ; * * * \\
p<<0.001 \\
\text { Adjusted } R \text {-squared: } 0.7948\end{array}$ \\
\hline
\end{tabular}

As it can be seen from Table 4, the results prove the hypothesis that e-government development has a positive and significant effect on corruption control in any country.

\section{E-Government Development $\rightarrow$ Government Effectiveness (EGDI $\rightarrow$ GE)}

H4: E-Government development (effectiveness and quality of service delivery) has a positive and significant effect on government effectiveness in any country.

Table 5

Regression coefficients on government effectiveness (GE)

\begin{tabular}{|c|c|c|c|c|}
\hline $\begin{array}{c}\text { Independent } \\
\text { Variable }\end{array}$ & $\beta$ & $t$ & $\operatorname{Pr}(>|t|)$ & Result \\
\hline EGDI & & 3.795 & $0.00223 * *$ & Supported (H4) \\
\hline & \multicolumn{4}{|c|}{$\begin{array}{l}\text { Significance codes: } \\
* p<0.05, * * p<0.01 ; * * * p<0.001 \\
\text { Adjusted } R \text {-squared: } 0.4891\end{array}$} \\
\hline
\end{tabular}

As Table 5 illustrates, the results of our analysis prove the hypothesis that e-government development has a positively significant influence on government effectiveness. Our results thus agree with those of the studies referenced in the preceding sections, which assert that e-government contributes to people's trust in the government and the government's accountability (characteristics of an effective government).

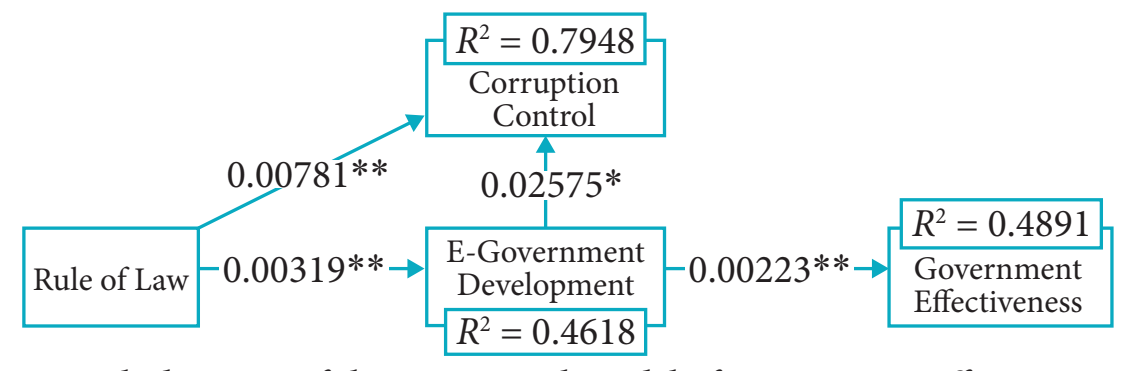

Figure 2. Path diagram of the conceptual model of government effectiveness based on the development of e-government 
Our observations agree with the study of Kim [13], who concludes that the rule of law is a fundamental precondition of government effectiveness and an important tool in fighting corruption (see Figure 2).

From the theoretical standpoint, our conceptual model affirms the fact that adherence to the rule of law influences corruption control and e-government development; e-government development, in its turn, influences corruption control and government effectiveness.

\section{Discussion}

This study presents e-government as a key factor that shapes government effectiveness. The model we built and the analysis of the available data indicate that the rule of law is significant in controlling corruption and creating room for e-government development. E-government development also significantly influences the control of corruption and enhances government effectiveness.

The results obtained are in line with the study of Diez et al. [29], who found that states which adhere to the rule of law have an enabling environment for e-government to flourish because it encourages e-participation. Following this line of reasoning, it can be concluded that the development of e-government creates transparency in governance and enhances trust among citizenry and, therefore, helps fight corruption [30; 31]. Moreover, our results agree with those of Smith
[32], who pointed out that e-government helps the state address vital questions and needs of citizens.

This study's findings contribute to the theoretical discussion of e-government development by highlighting its role in ensuring effective governance. The model is highly recommended as a measurement tool to assess effective governance in any given country. The constituents of the model have proven to be important indicators, thus their combination may be useful for policy-and decision-makers.

\section{Conclusion}

The above-described study involved the analysis of selected development indicators (factors) the rule of law, corruption control, e-government development, and government effectiveness - and the role they play collectively in ensuring government effectiveness (with e-government as the core component). We found that the rule of law together with promotion of e-government systems enhances the efficiency of public services. Thus, creation of a citizen-centric e-government environment becomes one of the crucial tasks for modern states in the digital era.

Just as every research has certain hindering factors, this study is no exception. To begin with, for our model, we used a limited number of factors, so further research is needed to expand the model and test other contributing factors. Moreover, 52 it would be productive to use cross-sectional panel data for different time periods.

\section{References}

1. Rust, R. T., \& Kannan, P. K. (2016). The era of e-service. In Rust, R. T., \& Kannan, P. K. (Eds), E-service: New directions in theory and practice (pp. 15-34). Routledge.

2. Manda, M. I. \& Backhouse, J. (2016). Addressing trust, security and privacy concerns in e-government integration, interoperability and information sharing through policy: a case of South Africa. In: CONF-IRM. Cape Town, South Africa, 18-20 May, 2016 (p. 67).

3. Borzdy, Y. (2009). Modern Approaches in Modeling of E-government. Business informatics, (4), 60-67.

4. Medvedeva, M. A., Davletbaev, R. H., Berg, D. B., Nazarova, J. J., \& Parusheva, S. S. (2016). Industrial entrepreneurial network: Structural and functional analysis. In Pasheva, N. Popivanov, \& G. Venkov (Eds.), Applications of mathematics in engineering and economics (AMEE'16) (Vol. 1789). [020018] (AIP Conference Proceedings; Vol. 1789). American Institute of Physics Publising LLC. DOI: $\underline{10.1063 / 1.4968439}$

5. Berntzen, L. (2013). Citizen-centric eGovernment Services. In The Sixth International Conference on Advances in Human oriented and Personalized Mechanisms, Technologies, and Services (CENTRIC), October 27 - November 1, 2013, Venice, Italy (pp. 132-136).

6. Alryalat, M. A. A., Rana, N. P., Sahu, G. P., Dwivedi, Y. K. \& Tajvidi, M. (2017). Use of social Media in Citizen-Centric Electronic Government Services: A literature analysis. International Journal of Electronic Government Research (IJEGR), 13(3), 55-79. DOI: 10.4018/IJEGR.2017070104 
7. Kolsaker, A., \& Lee-Kelley, L. (2006). Citizen-centric e-government: a critique of the UK model. Electronic Government, an International Journal, 3(2), 127-138. DOI: 10.1504/eg.2006.009214

8. Ibrahem Zahran, D., Al-Nuaim, H. A., Rutter, M. J., \& Benyon, D. (2015). A Critical Analysis of M-Government Evaluation Models at National and Local Municipal Levels. Electronic Journal of e-Government, 13(1), 28-42.

9. Bakunzibake, P., Grönlund, Å., \& Klein, G. O. (2016). E-Government Implementation in Developing Countries: Enterprise Content Management in Rwanda. In $15^{\text {th }}$ IFIP Electronic Government $(E G O V) / 8^{\text {th }}$ Electronic Participation (ePart) Conference, Univ Minho, Guimaraes, Portugal, September 5-8, 2016 (pp. 251-259). IOS Press. DOI: 10.3233/978-1-61499-670-5-251

10. Ziemba, E., Papaj, T., \& Hacura, M. J. (2015). E-government success factors: a perspective on government units. Issues in Information Systems, 16(2), 16-27.

11. Sigwejo, A., \& Pather, S. (2016). A Citizen-Centric Framework For Assessing E-Government Effectiveness. The Electronic Journal of Information Systems in Developing Countries, 74(1), 1-27. DOI: $10.1002 / j .1681-4835.2016 . t b 00542 . \mathrm{x}$

12. Eger, J. M., \& Maggipinto, A. (2009). Technology as a tool of transformation: e-Cities and the rule of law. In A. D’Atri, \& D. Saccà (Eds.), Information Systems: People, Organizations, Institutions, and Technologies (pp. 23-30). Physica-Verlag HD. DOI: 10.1007/978-3-7908-2148-2 4

13. Kim, C. K. (2014). Anti-corruption initiatives and e-government: a cross-national study. Public Organization Review, 14(3), 385-396. DOI: 10.1007/s11115-013-0223-1

14. Haggard, S., MacIntyre, A., \& Tiede, L. (2008). The rule of law and economic development. Annual Review of Political Science, 11, 205-234. DOI: 10.1146/annurev.polisci.10.081205.100244

15. Ruhode, E. (2016). E-Government for Development: A Thematic Analysis of Zimbabwe's Information and Communication Technology Policy Documents. The Electronic Journal of Information Systems in Developing Countries, 73(1), 1-15. DOI: 10.1002/j.1681-4835.2016.tb00532.x

16. Aladwani, A. M. (2016). Corruption as a source of e-Government projects failure in developing countries: A theoretical exposition. International Journal of Information Management, 36(1), 105-112.

17. Ifinedo, P. (2011). Examining Influences on eGovernment Growth in the Transition Economies of Central and Eastern Europe: Evidence from Panel Data. In Proceedings of the $11^{\text {th }}$ European Conference on e-Government (pp. 310-319). Ljubljana: Academic Conferences and Publishing International Limited.

18. Krishnan, S., \& Teo, T. (2012). Does governance matter? Investigating the impact of governance on E-government maturity.

19. Krishnan, S., \& Teo, T. S. (2012). Moderating effects of governance on information infrastructure and e-government development. Journal of the American Society for Information Science and Technology, 63(10), 1929-1946. DOI 10.1002/asi.22660

20. Lewis, S. (2015). Qualitative inquiry and research design: Choosing among five approaches. Health promotion practice, 16(4), 473-475. DOI: 10.1177/1524839915580941

21. Richey, R. C., \& Klein, J. D. (2014). Design and development research: Methods, strategies, and issues. Routledge.

22. Wang, J. (2016). The Rise of Singapore as International Financial Centre: Political Will, Industrial Policy, and Rule of Law. In Hu, J., Vanhullebusch, M., \& Harding, A. (Eds.), Finance, Rule of Law and Development in Asia: Perspectives from Singapore, Hong Kong and Mainland China (pp. 3-17). Leiden/Boston: Brill Academic Publishers.

23. Mungiu-Pippidi, A., \& Dadašov, R. (2016). Measuring control of corruption by a new index of public integrity. European Journal on Criminal Policy and Research, 22(3), 415-438. DOI: 10.1007/ $\underline{\text { s10610-016-9324-Z }}$

24. Srivastava, S. C., \& Teo, T. S. (2008). The relationship between e-government and national competitiveness: The moderating influence of environmental factors. Communications of the association for information systems, 23, Article 5, 73-94. DOI: 10.17705/1CAIS.02305

25. Al Raee, M., Ritzen, J., \& de Crombrugghe, D. (2017). Innovation policy \& labour productivity growth: Education, research \& development, government effectiveness and business policy. The UNU-MERIT WORKING Paper Series, 2017-19. 
26. Jiao, H., Koo, C. K., \& Cui, Y. (2015). Legal environment, government effectiveness and firms' innovation in China: examining the moderating influence of government ownership. Technological Forecasting and Social Change, 96, 15-24. DOI: 10.1016/j.techfore.2015.01.008

27. Silva, C. N. (2017). United Nations E-Government Survey 2016: E-Government in Support of Sustainable Development.

28. Berenson, M., Levine, D., Szabat, K. A., \& Krehbiel, T. C. (2012). Basic business statistics: Concepts and applications. Pearson higher education AU.

29. Diez, D. M., Barr, C. D., \& Cetinkaya-Rundel, M. (2012). OpenIntro statistics. $2^{\text {nd }}$ ed. CreateSpace Independent Publishing Platform.

30. Ionescu, L. (2013). The potential role of e-government in mitigating corruption. Economics, Management and Financial Markets, 8(3), 126.

31. Abu-Shanab, E. A. (2013). The Relationship between Transparency and E-Government: An Empirical Support. EGOV/ePart Ongoing Research, 221, 84-91. Retrieved from: http://subs.emis. de/LNI/Proceedings/Proceedings221/84.pdf (Accessed 10 August 2018)

32. Smith, R. F. I. (2016). Improving governance and services: can e-government help? Chinese Public Administration Review, 3(3/4), 62-70.

\section{Authors}

Ebenezer Agbozo - Researcher, Graduate School of Economics and Management, Ural Federal University (19 Mira St., 620002, Ekaterinburg, Russia); e-mail: eagbozo@urfu.ru

Benjamin K. Asamoah - Researcher, Graduate School of Economics and Management, Ural Federal University (19 Mira St., 620002, Ekaterinburg, Russia); e-mail: lipsy165@gmail.com

ARTICLE INFO: received March 7, 2019; accepted June 4, 2019

\section{Информация об авторах}

Агбозо Эбенезер - инженер-исследователь, Высшая школа экономики и менеджмента, Уральский федеральный университет им. первого Президента России Б. Н. Ельцина (620002, Россия, г. Екатеринбург, ул. Мира, 19); e-mail: eagbozo@urfu.ru

Асамоа Бенджамин - инженер-исследователь, Высшая школа экономики и менеджмента, Уральский федеральный университет им. первого Президента России Б. Н. Ельцина (620002, Россия, г. Екатеринбург, ул. Мира, 19); e-mail: lipsy165@gmail.com

ИНФОРМАЦИЯ О СТАТЬЕ: дата поступления 7 марта 2019 г.; дата принятия к печати 4 июня 2019 г.

This work is licensed under a Creative Commons Attribution 4.0 International License

Эта работа лицензируется в соответствии с Creative Commons Attribution 4.0 International License 